\title{
Silage Quality of King Grass (Pennisetum purpureophoides) Treated with Epiphytic Lactic Acid Bacteria and Tannin of Acacia
}

\author{
B. Santoso ${ }^{\mathrm{a},}$, B. Tj. Hariadia ${ }^{\mathrm{a}}$ H. Manik ${ }^{\mathrm{b}}$, \& H. Abubakarc \\ a Department of Animal Nutrition, Faculty of Animal Science, Fishery and Marine Science, State University of Papua \\ ${ }^{b}$ Department of Animal Production, Faculty of Animal Science, Fishery and Marine Science, State University of Papua \\ 'Department of Biology, Faculty of Mathematics and Natural Science, State University of Papua \\ Jln. Gunung Salju, Amban, Manokwari - Papua Barat, Indonesia \\ (Received 29-10-2010; accepted 14-04-2011)
}

\begin{abstract}
ABSTRAK
Tujuan penelitian ini adalah untuk mengevaluasi kualitas silase rumput raja (Pennisetum purpureophoides) dengan penambahan bakteri asam laktat (BAL) epifit yang diperoleh dari ekstrak rumput terfermentasi (ERT) atau dikombinasi dengan tanin dari akasia. Percobaan disusun menggunakan rancangan acak lengkap dengan 6 perlakuan dan 3 ulangan. Perlakuan meliputi: (A) rumput raja tanpa aditif sebagai kontrol; (B) rumput raja + 3\% ERT (v/b); (C) rumput raja + 3\% ERT (v/b) + $10 \mathrm{ml}$ ekstrak akasia $(50 \mathrm{~g} / 100 \mathrm{ml})$; (D) rumput raja $+3 \%$ ERT $(\mathrm{v} / \mathrm{b})+10 \mathrm{ml}$ ekstrak akasia $(50 \mathrm{~g} / 75 \mathrm{ml}) ;(\mathrm{E})$ rumput raja $+3 \%$ ERT (v/b) + $10 \mathrm{ml}$ ekstrak akasia $(50 \mathrm{~g} / 50 \mathrm{ml}) ;(\mathrm{F})$ rumput raja + 3\% ERT (v/b) + $10 \mathrm{ml}$ ekstrak akasia $(50 \mathrm{~g} / 25 \mathrm{ml})$. Sebanyak $250 \mathrm{~g}$ bahan silase diensilase di dalam silo botol berukuran $400 \mathrm{ml}$ dan disimpan pada suhu ruang $\left(28^{\circ} \mathrm{C}\right)$ selama 30 hari. Variabel yang diukur adalah karakterisistik ERT, karakteristik fermentasi, dan komposisi kimia silase. Data dianalisis menggunakan analisis varians dan perbedaan antar perlakuan diuji menggunakan uji wilayah ganda Duncan. Hasil penelitian menunjukkan bahwa jumlah BAL pada ERT meningkat dari $0,8 \times 10^{7} \mathrm{cfu} / \mathrm{ml}$ menjadi $2,9 \times 10^{7} \mathrm{cfu} / \mathrm{ml}$ setelah diinkubasi selama 2 hari. Konsentrasi asam laktat pada silase dengan penambahan ERT atau dikombinasi dengan tanin akasia $(\mathrm{B}, \mathrm{C}, \mathrm{D}, \mathrm{E}$, dan $\mathrm{F})$ lebih tinggi $(\mathrm{P}<0,01)$ dibanding silase $\mathrm{A}$ (kontrol). Silase dengan penambahan ERT atau dikombinasi dengan tanin akasia (C, D, E, dan F) mempunyai nilai $\mathrm{pH}$ yang lebih rendah dibandingkan silase $\mathrm{A}$ dan $\mathrm{B}$. Konsentrasi $\mathrm{N}-\mathrm{NH}_{3}$ menurun sejalan dengan meningkatnya konsentrasi tanin akasia. Konsentrasi asam butirat lebih rendah pada silase B, C, D, E, dan F dibanding silase A. Penambahan ERT yang dikombinasikan dengan tanin yang berasal dari daun akasia meningkatkan kualitas silase rumput raja.
\end{abstract}

Kata kunci: silase, rumput, bakteri asam laktat, tanin

\section{ABSTRACT}

The aim of this study was to evaluate the silage quality of king grass (Pennisetum purpureophoides) treated with addition of epiphytic lactic acid bacteria (LAB) prepared from fermented grass extract (FGE) or combined with tannin of acacia. Experiment was arranged to a completely randomized design with six treatments and three replications. Treatments were (A) king grass without additive as a control; (B) king grass $+3 \%(\mathrm{v} / \mathrm{w})$ of FGE; (C) king grass $+3 \%(\mathrm{v} / \mathrm{w})$ of FGE $+10 \mathrm{ml}$ of acacia extract $(50 \mathrm{~g} / 100 \mathrm{ml}) ;(D)$ king grass $+3 \%$ of FGE $(\mathrm{v} / \mathrm{w})+10 \mathrm{ml}$ of acacia extract $(50 \mathrm{~g} / 75 \mathrm{ml}) ;(\mathrm{E})$ king grass + $3 \%$ of FGE $(\mathrm{v} / \mathrm{w})+10 \mathrm{ml}$ of acacia extract $(50 \mathrm{~g} / 50 \mathrm{ml})$, and (F) king grass $+3 \%$ of FGE $(\mathrm{v} / \mathrm{w})+10 \mathrm{ml}$ of acacia extract $(50 \mathrm{~g} / 25 \mathrm{ml})$. About $250 \mathrm{~g}$ of silage materials were ensiled in $400 \mathrm{ml}$ bottle silos at room temperatures (approximately $28^{\circ} \mathrm{C}$ ) for 30 days. Variables measured were characteristics of FGE, fermentation characteristics and chemical composition of silage. Data were analyzed by analysis of variance and the significance differences among means were tested by the Duncan's multiple range test. Results showed that the number of lactic acid bacteria in FGE increased from $0.8 \times 10^{7} \mathrm{cfu} / \mathrm{ml}$ to $2.9 \times 10^{7} \mathrm{cfu} / \mathrm{ml}$ after 2 days anaerobic incubation. Concentration of lactic acid in silages with addition of FGE or combined with tannin of acacia $(B, C, D, E$, and $F)$ were higher $(P<0.01)$ than that of silage A (control). Silages with addition of FGE combined with tannin of acacia (C, D, E, and F) had lower $\mathrm{pH}$ value than that of silages $\mathrm{A}$ and $\mathrm{B}$. Concentrations of $\mathrm{NH}_{3}-\mathrm{N}$ decreased with increasing concentration of tannin. Butyric acid concentration decreased in silages B, C, D, E, and F as compared to that in silage 


\section{A. Addition of FGE combined with tannin prepared from acacia leaf improved fermentation quality of king grass silage.}

Key words: silage, grass, lactic acid bacteria, tannin

\section{INTRODUCTION}

It is recognized that tropical grasses have low water soluble carbohydrate content, high buffering capacity and low lactic acid bacteria (LAB) number (Yahaya et al., 2004b). These properties result in low lactic acid production; hence it is difficult to produce good-quality silage from tropical grasses. The epiphytic microorganisms existed naturally in forage crops are responsible for silage fermentation and also influence the effectiveness of silage bacterial inoculation. However, the number of LAB is usually low and vary depended on growing crops (McDonald, 1981).

Fermented grass extract of epiphytic lactic acid bacteria (FGE) is prepared by culturing microorganism adherent to the grass materials before preparation of silage and the grown microorganism are used as a starter of silage fermentation. Masuko et al. (2002) revealed that FGE was prepared by macerating grass in water and incubating it anaerobically at $30{ }^{\circ} \mathrm{C}$ for 2 days. Previous studies of Masuko et al. (2002); Yahaya et al. (2004b); Bureenok et al. (2006); Horiguchi \& Takahashi (2007) found that addition of fermented grass extract on silage materials could increase lactic acid production, decrease $\mathrm{NH}_{3}-\mathrm{N}$ concentration, increase lactic acid bacteria population, and improve fermentation quality of grasses and green soybean stover silage. In addition, Wang et al. (2009) concluded that fermented grass extract can be used as a good source of LAB for direct cut alfalfa silage.

During the ensiling process of forage, extensive proteolysis occurs due to the combined action of both plant and microbial enzymes resulting in conversion of most protein to non-protein nitrogen (NPN) fractions mainly amino acid $\mathrm{N}$, peptide $\mathrm{N}$, and ammonia $\mathrm{N}$ (Owens et al. 2002; Givens \& Rulquin, 2004). The rapid rate of degradation of silage NPN and soluble-protein N in the rumen results in a pronounced peak in rumen ammonia concentration following ingestion. Excess quantities of ammonia in the rumen is absorbed into the blood stream, converted to urea in liver and subsequently excreted in the urine, contributing to environmental pollution (Swensson, 2003).

Tannins are polyphenolic compounds of plant origin that have ability to bind protein. It has been reported that tannin-containing species such as quebracho, chestnut, residues of green tea and black tea reduced protein degradation during ensiling and protein disappearance in the rumen (Salawu et al., 2001; Kondo et al., 2004; Tabacco et al., 2006; Santoso et al. 2007) by inhibiting plant and microbial enzymes or by forming complexes with protein (McSweeney et al., 2001). Hariadi \& Santoso (2010) reported that acacia leaf (Acacia mangium Willd) contains $5.4 \%$ total tannin; hence it is potentially used as silage additive to protect protein degradation during ensiling.
The objective of this experiment was to evaluate the fermentation quality of king grass (Pennisetum purpureophoides) silage treated with addition of epiphytic LAB prepared from fermented grass extract or combined with tannin of acacia.

\section{MATERIALS AND METHODS}

\section{Forage Material}

King grass (Pennisetum purpureophoides) was planted in a $9 \mathrm{~m}^{2}$ plot without fertilizer at the experimental field of Faculty of Animal Science, Fishery and Marine Science, State University of Papua in Manokwari. Grass was harvested with a hand clipper in May 2009 after 50 days of regrowth defoliation. The experimental field is located at $134^{\circ} 04^{\prime}$ longitude and $00^{\circ} 48^{\prime}$ latitude. The area is located at an altitude of $110 \mathrm{~m}$ above sea level. The mean annual rainfall and temperature were 159.9 $\mathrm{mm}$ and $27.1^{\circ} \mathrm{C}$, respectively.

\section{Preparations of Fermented Grass Extract and Acacia Extract}

Preparation of FGE according to modified of Bureenok et al. (2006) procedure as previously described by Santoso et al. (2009). The FGE was prepared using 220 $\mathrm{g}$ of fresh king grass, which was macerated in $1000 \mathrm{ml}$ of distilled water using a high-speed blender for $4 \mathrm{~min}$. The macerated material was filtered through two layers of cheesecloths, and $600 \mathrm{ml}$ of filtrate was collected in erlenmeyer glass containing $18 \mathrm{~g}$ of glucose. The filtrate was mixed well and incubated anaerobically for $48 \mathrm{~h}$ at $30{ }^{\circ} \mathrm{C}$. At the end of $48 \mathrm{~h}, \mathrm{FGE}$ was used as source of $\mathrm{LAB}$. The number of LAB in the FGE was counted before the experiments by using de Man, Rogosa, and Sharpe which were incubated for 3 days at $35{ }^{\circ} \mathrm{C}$ (Bureenok et al., 2006).

About $50 \mathrm{~g}$ of finely acacia leaf were weighed into $100 \mathrm{ml}$ beaker glass and added $25 \mathrm{ml}$ of distilled water. The same procedure was also performed for 50,75 , and $100 \mathrm{ml}$ of distilled water. The mixtures were boiled for $10 \mathrm{~min}$ on a hotplate and filtered through 2 layers of cheesecloth. The filtrates were collected and stored at 4 ${ }^{\circ} \mathrm{C}$ for further use.

\section{Silage Preparation and Treatments}

The fresh king grass was wilted at room temperature (approximately $28{ }^{\circ} \mathrm{C}$ ) for $24 \mathrm{~h}$ and chopped into 3-5 cm. The chopped grass was thoroughly mixed and a representative samples obtained. Total of 6 treatments were as follows (A) king grass without additive as the control; (B) king grass $+3 \%(\mathrm{v} / \mathrm{w})$ of FGE; (C) king grass $+3 \%(\mathrm{v} / \mathrm{w})$ of FGE $+10 \mathrm{ml}$ of acacia extract $(50 \mathrm{~g} / 100$ 
$\mathrm{ml}$ ); (D) king grass $+3 \%$ of FGE (v/w) $+10 \mathrm{ml}$ of acacia extract $(50 \mathrm{~g} / 75 \mathrm{ml})$; (E) king grass $+3 \%$ of FGE $(\mathrm{v} / \mathrm{w})+$ $10 \mathrm{ml}$ of acacia extract $(50 \mathrm{~g} / 50 \mathrm{ml})$, and $(\mathrm{F})$ king grass $+3 \%$ of FGE $(\mathrm{v} / \mathrm{w})+10 \mathrm{ml}$ of acacia extract $(50 \mathrm{~g} / 25 \mathrm{ml})$. Both FGE and acacia extract were sprayed onto silage materials using a hand sprayer and subsequently mixed by hand. Based on the concentration of LAB in FGE, the final application was $5.8 \times 10^{6} \mathrm{cfu} / \mathrm{g}$ of fresh forage. Tannin concentration calculated in silage C, D, E, and F were $2.7,3.6,5.2$, and $10.3 \mathrm{~g} / \mathrm{kg}$, respectively. About 250 $\mathrm{g}$ of silage materials were packed into $400 \mathrm{ml}$ laboratory glass bottle silos. Each treatment was prepared in triplicate and the silos were stored in room temperature for 30 days.

\section{Analytical Procedure}

Dried samples were used to determine DM, ash, and crude protein (CP) according to the procedure of AOAC (2005). Procedure of Van Soest et al. (1991) was used to determine concentrations of neutral detergent fiber (NDF), acid detergent fiber (ADF) and acid detergent lignin (ADL). NDF was determined without the use of $\propto$-amylase and sodium sulfite.

A $20 \mathrm{~g}$ of silage was macerated with $70 \mathrm{ml}$ of distilled water and stored at $4{ }^{\circ} \mathrm{C}$ for $24 \mathrm{~h}$. It was than homogenized for $15 \mathrm{~min}$ by using a shaker and filtered through a Whatman No. 1542 filter paper. The filtrate was used to determine $\mathrm{pH}, \mathrm{VFAs}$, lactic acid and $\mathrm{NH}_{3}-\mathrm{N}$. The $\mathrm{pH}$ value was determined using a $\mathrm{pH}$ meter (Hanna $\mathrm{Hi}$ 9025). Concentrations of individual VFAs were analyzed using a gas chromatography (Varian CP-9002 GC, Shimadzu, Japan) equipped with flame ionization detector (FID) and stainless steel column $(1500 \mathrm{~mm} \times 3$ $\mathrm{mm}$ i.d). The pressure of nitrogen was $1.25 \mathrm{~kg} / \mathrm{cm}^{2}$. The temperature of injector oven, column oven and detector were 220,130 , and $220{ }^{\circ} \mathrm{C}$, respectively. Concentrations of lactic acid and $\mathrm{NH}_{3}-\mathrm{N}$ were analyzed according to the method of Barker \& Summerson (1941); Chaney \& Marbach (1962), respectively.

\section{Statistical Analysis}

Silage fermentation data were subjected to analysis of variance for a completely randomized design. Duncan's multiple range test was used to separate treatment means, when probability was less than 0.05 .

\section{RESULTS AND DISCUSSION}

\section{Characteristics of Fermented Grass Extract}

Table 1 depicts the result of $\mathrm{pH}$ value and LAB number in the fermented grass extract used as additive at ensiling. The epiphytic LAB number of the material grass was $0.8 \times 10^{7} \mathrm{cfu} / \mathrm{ml}$ fresh matter. After $48 \mathrm{~h}$ of incubation at $30{ }^{\circ} \mathrm{C}$, the LAB number in the FGE increased to $2.9 \times 10^{7} \mathrm{cfu} / \mathrm{ml}$. Increased LAB number resulted in high concentration of lactic acid, thereby decreasing in $\mathrm{pH}$ value from 6.71 to 3.51 . In previous study, Santoso et al. (2009) also reported that $\mathrm{pH}$ value of fermented grass
Table 1. The $\mathrm{pH}$ value and lactic acid bacteria (LAB) number in grass extract before and after incubation $48 \mathrm{~h}$

\begin{tabular}{lcc}
\hline & $\begin{array}{c}\text { Before } \\
\text { incubation }\end{array}$ & $\begin{array}{c}\text { After } \\
\text { incubation }\end{array}$ \\
\hline $\mathrm{pH}$ & 6,71 & 3,51 \\
$\mathrm{LAB}\left(\times 10^{7} \mathrm{cfu} / \mathrm{ml}\right)$ & 0,80 & 2,90 \\
\hline
\end{tabular}

extract prepared with king grass reduced from 6.41 to 3.45. The patterns of reduced $\mathrm{pH}$ value in fermented extracts of grass or legume, and increased LAB number after $48 \mathrm{~h}$ of incubation are agree with previous reports of Nishino \& Uchida (1999); Bureenok et al. (2006); Wang et al. (2009). Nishino \& Uchida (1999) revealed that several strains of LAB e.g. Lactobacillus plantarum, Lactobacillus viridescens, Lactobacillus fermentum, Pediococcus acidilactici were isolated from Lucerne, timothy and coksfoot fermented extracts. However predominant strains were different depended on the material crop used for fermented extract preparation.

\section{Fermentative Quality of the Silages}

Fermentation characteristics of king grass silage treated with epiphytic lactic acid bacteria and tannin of acacia are shown in Table 2. The $\mathrm{pH}$ values in silages of $C, D, E$ and $F$ were lower $(\mathrm{P}<0.01)$ than that of silage A (control). Lower $\mathrm{pH}$ value in silage treated with epiphytic LAB and acacia tannin could be due to higher lactic acid concentration in those silages. Seglar (2003) stated that lactic acid is the strongest of all silage acids and its presence will drop $\mathrm{pH}$ more effectively than the other volatile fatty acids. Even though, lower $\mathrm{pH}$ value found in silage treated with epiphytic LAB, however, the final $\mathrm{pH}$ value except silage $\mathrm{D}$ are still above than ideal silage $\mathrm{pH}$ of 4.0 to 4.5 . As reported by Chamberlain \& Wilkinson (1996) that secondary fermentation occurs when insufficient acid is produced by primary fermentation to reduce the $\mathrm{pH}$ to below a critical level of about 4.5 .

Concentration of lactic acid in silages of B, C, D, E and $\mathrm{F}$ were significantly $(\mathrm{P}<0.01)$ higher as compared to control silage (A). This result agrees with previous study on silages prepared with tropical grasses as reported by Yahaya et al. (2004a); Yahaya et al. (2004b); Bureenok et al. (2006), and lucerne silage by Nishino \& Uchida (1999); Filya et al. (2007); Wang et al. (2009). Increased lactic acid concentration in silage treated with epiphytic LAB could be due to increasing fermentation process by LAB which converts monosaccharide such as glucose and fructose to lactic acid. Higher concentration of lactic acid in silage has positive effect to animal due to it can be converted to propionic acid in the rumen. In a study by Takahashi et al. (2005), the molar proportion of propionic acid tended to increase, and the ratio of acetic acid to propionic acid decreased, at $4 \mathrm{~h}$ after feeding in sheep fed whole crop rice silage with epiphytic $\mathrm{LAB}$ prepared from fresh rice straw. Increased propionic acid concentration might be due to addition of epiphytic LAB to silage materials 
Table 2. Fermentation characteristics of king grass silage treated with epiphytic lactic acid bacteria and tannin of acacia after 30 days ensilage

\begin{tabular}{|c|c|c|c|c|c|c|c|c|}
\hline & \multicolumn{6}{|c|}{ Silages } & \multirow{2}{*}{ SEM } & \multirow{2}{*}{$\mathrm{P}$} \\
\hline & $\mathrm{A}$ & $\mathrm{B}$ & $\mathrm{C}$ & $\mathrm{D}$ & E & $\mathrm{F}$ & & \\
\hline $\mathrm{LAB}\left(\times 10^{7} \mathrm{cfu} / \mathrm{ml}\right)$ & 2.3 & 2.5 & 1.4 & 1.1 & 1.3 & 2.1 & 0.41 & 0.14 \\
\hline $\mathrm{pH}$ & $5.28^{\mathrm{A}}$ & $4.67^{\mathrm{AB}}$ & $4.52^{\mathrm{B}}$ & $4.31^{\mathrm{B}}$ & $4.61^{\mathrm{B}}$ & $4.56^{\mathrm{B}}$ & 0.14 & $<0.01$ \\
\hline Lactic acid (g/kg DM) & $0.6^{\mathrm{b}}$ & $43.2^{\mathrm{A}}$ & $39.7^{\mathrm{A}}$ & $39.2^{\mathrm{A}}$ & $42.6^{\mathrm{A}}$ & $37.4^{\mathrm{A}}$ & 6.23 & $<0.01$ \\
\hline $\mathrm{NH}_{3}-\mathrm{N}(\mathrm{g} / \mathrm{kg}$ total $\mathrm{N})$ & $289.7^{\mathrm{a}}$ & $159.7^{b}$ & $132.2^{\mathrm{b}}$ & $124.0^{\mathrm{b}}$ & $120.1^{b}$ & $105.8^{\mathrm{b}}$ & 39.3 & 0.05 \\
\hline Acetic acid (g/kg DM) & 73.0 & 95.2 & 110.0 & 44.1 & 75.8 & 69.2 & 29.51 & 0.71 \\
\hline Propionic acid (g/kg DM) & 11.6 & 3.9 & 9.6 & 6.2 & 6.3 & 0 & 3.50 & 0.30 \\
\hline Butyric acid (g/kg DM) & $25.6^{\mathrm{A}}$ & $4.7^{\mathrm{B}}$ & $4.0^{\mathrm{B}}$ & $6.3^{\text {B }}$ & $6.7^{\mathrm{B}}$ & $5.6^{\mathrm{B}}$ & 3.06 & 0.01 \\
\hline Total VFA (g/kg DM) & 110.2 & 103.8 & 123.6 & 56.5 & 88.7 & 74.8 & 27.15 & 0.56 \\
\hline
\end{tabular}

Note: Means in the same row followed by different letters are different $\left.{ }^{\mathrm{a}-\mathrm{b}} \mathrm{P}<0.05 ;{ }^{\mathrm{A}-\mathrm{B}} \mathrm{P}<0.01\right)$. A $=$ king grass without additive; $\mathrm{B}=\mathrm{king}$ grass $+3 \%$ ( $\mathrm{v} / \mathrm{w}$ ) of fermented grass extract (FGE); $\mathrm{C}=$ king grass $+3 \%(\mathrm{v} / \mathrm{w})$ of FGE $+10 \mathrm{ml}$ of acacia extract $(50 \mathrm{~g} / 100 \mathrm{ml}) ; \mathrm{D}=\mathrm{king}$ grass $+3 \%$ of FGE (v/w) + 10 $\mathrm{ml}$ of acacia extract $(50 \mathrm{~g} / 75 \mathrm{ml}) ; \mathrm{E}=\mathrm{king}$ grass $+3 \%$ of FGE $(\mathrm{v} / \mathrm{w})+10 \mathrm{ml}$ of acacia extract $(50 \mathrm{~g} / 50 \mathrm{ml}) ; \mathrm{F}=\mathrm{king}$ grass $+3 \%$ of FGE $(\mathrm{v} / \mathrm{w})+10 \mathrm{ml}$ of acacia extract $(50 \mathrm{~g} / 25 \mathrm{ml})$.

changed the microbial populations in the rumen causing higher propionic acid fermentation. Alternatively, the higher concentration of lactic acid in the silage may have been metabolized into propionic acid by the rumen microorganisms. Propionic acid is then absorbed into blood stream via rumen wall and converted to glucose in the liver. Glucose formed is used by animal as energy source for maintenance, production and reproduction activities. In addition, Weinberg et al. (2004) concluded that LAB from silage has potential role as probiotic which beneficially affects the host animal by improving its intestinal microbial balance.

Concentration of lactic acid in silage treated with combination of LAB and acacia tannin (C, D, E and F) tended to be lower in comparison with silage treated with LAB alone (B). McSweeney et al. (2001) revealed that tannin has ability to bind to macromolecules such as structural carbohydrate and starch, thereby impairing their degradation. However, concentration of lactic acid in king grass silages treated LAB and acacia tannin were slightly lower than the ideal range of lactic acid concentration from 80 to $120 \mathrm{~g} / \mathrm{kg}$ DM.

Concentration of $\mathrm{NH}_{3}-\mathrm{N}$ in silages treated with $\mathrm{LAB}$ or combined with acacia tannin $(\mathrm{B}, \mathrm{C}, \mathrm{D}, \mathrm{E}$, and $\mathrm{F}$ ) were lower $(\mathrm{P}<0.05)$ than that of control silage. The finding was consistent with previous work of Nishino \& Uchida (1999) who found that use of fermented Lucerne extract increased lactic acid and greatly inhibited the clostridial activity to protect proteins from extensive degradation. As stated by Owens et al. (2002) that during ensiling protein is degraded to peptides and free amino acids by plant proteases. In addition, degradation of amino acids to ammonia and non-protein nitrogenous fraction is predominantly due to proteolytic clostridia. Chamberlain \& Wilkinson (1996) concluded that ammonia- $\mathrm{N}$ is as an indicator of the proportion of the total $\mathrm{N}$ which has been completely degraded during ensiling. Hence, concentration of ammonia- $\mathrm{N}$ is the best indicator of secondary fermentation. The growth of proteolytic clostridia, which degrade protein and amino acids to $\mathrm{NH}_{3}$ is inhibited by low pH (McDonald, 1981; Winters et al., 2000). This result was supported by the low $\mathrm{pH}$ values in silage $\mathrm{B}, \mathrm{C}, \mathrm{D}$, $\mathrm{E}$, and $\mathrm{F}$ compared to silage $\mathrm{A}$. This condition could depress the growth of proteolytic clostridia. Concentration of $\mathrm{NH}_{3}-\mathrm{N}$ reduced with increasing tannin addition in silage materials. This could be due to tannin can bind to protein and protect them from microbial degradation. Tabacco et al. (2006) reported that tannin were able to protect herbage proteins from plant/microbial enzyme hydrolysis during ensiling. Concentration of $\mathrm{NH}_{3}-\mathrm{N}$ in silage $C, D, E$, and $F$ decreased with increasing tannin concentration added in silage. This result is in agreement with previous study by Tabacco et al. (2006) that concentrations of $\mathrm{NH}_{3}-\mathrm{N}$ and NPN were reduced with increasing tannin concentration in silage. The normal range of $\mathrm{NH}_{3}-\mathrm{N}$ concentration in silage is 50 to $150 \mathrm{~g} \mathrm{NH}_{3}-\mathrm{N} / \mathrm{kg}$ DM. However, the target value for $\mathrm{NH}_{3}-\mathrm{N}$ is less than 50 $\mathrm{g} / \mathrm{kg}$ total N (Chamberlain \& Wilkinson, 1996). Based on $\mathrm{NH}_{3}-\mathrm{N}$ concentration, silage $\mathrm{C}, \mathrm{D}, \mathrm{E}$ and F could be classified in normal range of $\mathrm{NH}_{3}-\mathrm{N}$ concentration.

The VFAs comprise of acetic acid, propionic acid, butyric acid and other acids. The production of these acids is a reflection of an inefficient fermentation or of secondary fermentation of lactic acid to butyric acid and degradation of amino acids to ammonia with the production of acetic acid from the carbon skeleton of the amino acid (Chamberlain \& Wilkinson, 1996). Concentrations of total VFA, acetic acid and propionic acid were not significantly different $(\mathrm{P}>0.05)$ among treatments silage. However, silage treated with epiphytic LAB and tannin had lower $(\mathrm{P}<0.01)$ butyric acid concentration compared to control silage. The reduced butyric acid in those silages could be due to lower $\mathrm{pH}$ silage which may inhibit the activity of clostridia. McDonald (1981) stated that reducing $\mathrm{pH}$ silage prevented the growth of undesirable microbes e.g. listeria, clostridia, enterobacteriaceae, and moulds. Another possible explanation for the reduction of butyric acid in silage treated with acacia tannin (silage 
Table 3. Chemical composition (\%) of silages after 30 days ensilage

\begin{tabular}{|c|c|c|c|c|c|c|c|c|}
\hline & \multicolumn{6}{|c|}{ Silages } & \multirow{2}{*}{ SEM } & \multirow{2}{*}{$\mathrm{P}$} \\
\hline & A & B & $\mathrm{C}$ & $\mathrm{D}$ & $\mathrm{E}$ & $\mathrm{F}$ & & \\
\hline Dry matter (DM) & $17.5^{\mathrm{ab}}$ & $17.5^{\mathrm{ab}}$ & $18.2^{\mathrm{a}}$ & $16.2^{\mathrm{d}}$ & $16.8 \mathrm{bc}$ & $17.9^{\mathrm{a}}$ & 0.32 & 0.02 \\
\hline Organic matter (OM) & 94.6 & 95.3 & 95.5 & 96.2 & 95.2 & 95.4 & 0.45 & 0.27 \\
\hline Crude protein $(\mathrm{CP})$ & $12.8^{\mathrm{B}}$ & $16.2^{\mathrm{A}}$ & $15.7^{\mathrm{A}}$ & $15.3^{\mathrm{A}}$ & $15.7^{\mathrm{A}}$ & $15.7^{\mathrm{A}}$ & 0.19 & $<0.01$ \\
\hline Neutral detergent fiber (NDF) & $71.0^{\mathrm{A}}$ & $65.3^{\mathrm{B}}$ & $68.0^{\mathrm{AB}}$ & $67.3^{\text {в }}$ & $67.9^{\mathrm{AB}}$ & $66.9^{\mathrm{B}}$ & 0.96 & $<0.01$ \\
\hline Acid detergent fiber (ADF) & $43.4^{\mathrm{a}}$ & $41.7^{\mathrm{abc}}$ & $40.2^{\mathrm{c}}$ & $40.7^{\mathrm{bc}}$ & $42.5^{\mathrm{ab}}$ & $41.8^{\mathrm{abc}}$ & 0.55 & 0.02 \\
\hline Hemicellulose & $28.6^{\mathrm{A}}$ & $23.5^{\mathrm{B}}$ & $27.8^{\mathrm{A}}$ & $26.6^{\mathrm{AB}}$ & $25.4^{\mathrm{AB}}$ & $25.1^{\mathrm{AB}}$ & 0.79 & $<0.01$ \\
\hline
\end{tabular}

Note: Means in the same row followed by different letters are different $\left({ }^{\mathrm{a}-\mathrm{b}} \mathrm{P}<0.05 ;{ }^{\mathrm{A}-\mathrm{B}} \mathrm{P}<0.01\right)$. $\mathrm{A}=\mathrm{king}$ grass without additive; $\mathrm{B}=\mathrm{king}$ grass $+3 \%$ ( $\left.\mathrm{v} / \mathrm{w}\right)$ of fermented grass extract (FGE); C= king grass $+3 \%(\mathrm{v} / \mathrm{w})$ of FGE $+10 \mathrm{ml}$ of acacia extract $(50 \mathrm{~g} / 100 \mathrm{ml}) ; \mathrm{D}=\mathrm{king}$ grass $+3 \%$ of FGE (v/w) + 10 $\mathrm{ml}$ of acacia extract $(50 \mathrm{~g} / 75 \mathrm{ml}) ; \mathrm{E}=$ king grass $+3 \%$ of FGE $(\mathrm{v} / \mathrm{w})+10 \mathrm{ml}$ of acacia extract $(50 \mathrm{~g} / 50 \mathrm{ml}) ; \mathrm{F}=\mathrm{king}$ grass $+3 \%$ of FGE $(\mathrm{v} / \mathrm{w})+10 \mathrm{ml}$ of acacia extract $(50 \mathrm{~g} / 25 \mathrm{ml})$.

C, D, E and F) might be due to inhibited the activity of clostridia. It is well known that clostridia are responsible for most of the butyric acid in silage (McDonald, 1981).

Visually, there were no moulds on the top of silages treated with acacia tannin. This was probably due to toxic effect of tannin to silage moulds. This result is supported with previous study of McDonald (1981) that higher tannin in the silage reduced the activity of moulds.

\section{Chemical Composition of Silages}

Chemical composition of silages treated with epiphytic LAB and tannin of acacia is given at Table 3. Dry matter content in six silages was still lower than the target value for DM in ideal silage as recommended by Chamberlain \& Wilkinson (1996). The lower DM content in all silages could be attributed to DM content of king grass used as silage material was less than $20 \%$. The OM content in silage A was similar to silages treated with epiphytic LAB and tannin of acacia. Concentration of $\mathrm{CP}$ in silages treated with epiphytic LAB and tannin of acacia was higher $(\mathrm{P}<0.01)$ than that of control silage. The higher $\mathrm{CP}$ content in those silages could be due to lower activity proteolytic as resulted by low in $\mathrm{pH}$ value and protein protection by tannin acacia. Other explanation for higher $\mathrm{CP}$ content in silage treated with epiphytic $\mathrm{LAB}$ and tannin of acacia is addition of protein obtained from grass and acacia extracts.

The NDF content in silages B, D, and F was lower $(\mathrm{P}<0.01)$ than that of control silage. Silages $\mathrm{C}$ and $\mathrm{D}$ had lower $(\mathrm{P}<0.05)$ ADF content compared with control silage. This results, however is in agreement with previous studies of Yahaya et al. (2004b); de Oliveira et al. (2007). One of the explanations for the lower NDF and ADF in those silage is that enzymatic action e.g. hemicellulases, cellulase present in the original forage on cell wall during ensiling. Decreased NDF and ADF concentrations in silage treated with epiphytic LAB or combined with tannin of acacia had beneficial effect of silage nutritive value and leading to an increase in silage digestibility in the rumen.

\section{CONCLUSION}

Fermented grass extract prepared from king grass could be used as a good source of lactic acid bacteria pre-ensiling. Addition of epiphytic LAB or combined with acacia tannin have beneficial effect on fermentation and nutritive qualities of king grass silage indicated by a high lactic acid production, low $\mathrm{pH}$ value, as well as concentrations of $\mathrm{NH}_{3}-\mathrm{N}$ and butyric acid, high crude protein content, and low cell wall component contents i.e. NDF, ADF, and hemicellulose compared with control silage.

\section{ACKNOWLEDGEMENTS}

The research grant was provided by the State University of Papua (Contract No. 037/SP2H/PP/D2M/ III/2009). The authors are grateful to Nurhaida K. Tero for technical assistant during experiment.

\section{REFERENCES}

[AOAC] Association of Official Analytical Chemists. 2005. Official Methods of Analysis. 17 ${ }^{\text {th }}$ Ed. Washington: AOAC International.

Barker, S. B. \& W. H. Summerson. 1941. The colorimetric determination of lactic acid in biology material. J. Biol. Chem. 138: 535-554.

Bureenok, S., T. Namihira, S. Mizumachi, Y. Kawamoto, \& T. Nakada. 2006. The effect of epiphytic lactic acid bacteria with or without different byproduct from defatted rice bran and green tea waste on napiergrass (Pennisetum purpureum Shumach) silage fermentation. J. Sci. Food Agric. 86: 1073-1077.

Chamberlain, A. T. \& J. M. Wilkinson. 1996. Feeding the Dairy Cow. Chalcombe Publications, Lincoln, UK.

Chaney, A. L. \& E. P. Marbach. 1962. Modified reagents for determination of urea and ammonia. Clin. Chem. 8: 130-132.

de Oliveira, S. G., T. T. Berchielli, R. A. Reis, M. E. Vechetini, \& M. S. Pedreira. 2009. Fermentative characteristics and aerobic stability of sorghum silages containing different tannin levels. Anim. Feed Sci. Technol. 154: 1-8.

Filya, I., R. E. Muck \& F. E. Contreras-Govea. 2007. Inoculant effects on alfalfa silage: fermentation products and nutritive value. J. Dairy Sci. 90: 5108-5114. 
Givens, D. I. \& H. Rulquin. 2004. Utilisation by ruminants of nitrogen compounds in silage-based diets. Anim. Feed Sci. Technol. 114: 1-18.

Hariadi, B. Tj. \& B. Santoso. 2010. Evaluation of tropical plants containing tannin on in vitro methanogenesis and fermentation parameters using rumen fluid. J. Sci. Food Agric. 90:456-461.

Horiguchi, K. \& T. Takahashi. 2007. Fermentation quality and nutritive value of green soybean stover silage. Grassl. Sci. 53: 27-31.

Kondo, M., K. Kita, \& H. Yokota. 2004. Feeding value to goats of whole-crop oat ensiled with green tea waste. Anim. Feed Sci. Technol. 113: 71-81.

Masuko, T., Y. Hariyama, Y. Takahashi, L. M. Cao, M. Goto, \& M. Ohshima. 2002. Effect of addition of fermented juice of epiphytic lactic acid bacteria prepared from timothy and orchardgrass on fermentation quality of silages. Grassl. Sci. 48: 120-125.

McDonald, P. 1981. The Biochemistry of Silage. John Wiley \& Sons, Ltd. New York.

McSweeney, C. S., B. Palmer, D. M. McNeill, \& D. O. Krause. 2001. Microbial interactions with tannins: nutritional consequences for ruminants. Anim. Feed Sci. Technol. 91: 83-93.

Nishino, N. \& S. Uchida. 1999. Laboratory evaluation of previously fermented juice as a fermentation stimulant for lucerne silage. J. Sci. Food. Agric. 79: 1285-1288.

Owens, V. N., K. A. Albrecht, \& R. E. Muck. 2002. Protein degradation and fermentation characteristics of unwilted red clover and alfalfa silage harvested at various times during the day. Grass Forage Sci. 57: 329-341.

Salawu, M. B., E. H. Warren, \& A. T. Adesogan. 2001. Fermentation characteristics, aerobic stability and ruminal degradation of ensiled pea/wheat bi-crop forages treated with two microbial inoculants, formic acid or quebracho tannins. J. Sci. Food. Agric. 81: 1263-1268.

Santoso, B., B. Tj. Hariadi, H. Manik, \& H. Abubakar. 2009. Kualitas rumput unggul tropika hasil ensilase dengan aditif bakteri asam laktat dari ekstrak rumput terfermentasi. Med. Pet. 32: 138-145.

Santoso, B., M. N. Lekitoo, \& Umiyati. 2007. Komposisi kimia dan degradasi nutrien silase rumput gajah yang diensilase dengan residu daun teh hitam. Anim. Prod. 9: 160-165.
Seglar, B. 2003. Fermentation Analysis and Silage Quality Testing Proceeding of the Minnesota Dairy Health Conference College of Veterinary Medicine, University of Minnesota. pp. 119-136.

Swensson, C. 2003. Relationship between content of crude protein in rations for dairy cows, in urine and ammonia release. Livest. Prod. Sci. 84:125-133.

Tabacco, E., G. Borreani, G. M. Crovetto, G. Galassi, D. Colombo, \& L. Cavallarin. 2006. Effect of chestnut tannin on fermentation quality, proteolysis, and protein rumen degradability of alfalfa silage. J. Dairy Sci. 89: 4736-4746.

Takahashi, T., K. Horiguchi, \& M. Goto. 2005. Effect of crushing rice and the addition of fermented juice of epiphytic lactic acid bacteria on the fermentation quality of whole crop rice silage, and its digestibility and rumen fermentation status in sheep. Anim. Sci. J. 76: 353-358.

Van Soest, P. J., J. B. Robertson, \& B. A. Lewis. 1991. Methods for dietary fiber, neutral detergent fiber, and nonstarch polysaccharides in relation to animal nutrition. J. Dairy Sci. 74: 3583-3597.

Wang, J., J. Q. Wang, H. Zhou, \& T. Feng. 2009. Effects of addition of previously fermented juice prepared from alfalfa on fermentation quality and protein degradation of alfalfa silage. Anim. Feed Sci. Technol. 151: 280-290.

Weinberg, Z. G., R. E. Muck, P. J. Weimer, Y. Chen, \& M. Gamburg. 2004. Lactic acid bacteria used in inoculants for silage as a probiotics for ruminants. Appl. Biochem. Biotech. 118: 1-10.

Winters, A. L., J. E. Cockburn, M. S. Dhanoa, \& R. J. Merry. 2000. Effects of lactic acid bacteria in inoculants on changes in amino acid composition during ensilage of sterile and nonsterile ryegrass. J. Appl. Microbiol. 2000, $89,442-451$

Yahaya, M. S., M. Goto, W. Yimiti, B. Smerjai, \& Y. Kuwamoto. 2004a. Additive effects of fermented juice of epiphytic lactic acid bacteria and acetic acid on silo fermentation and ruminal degradability of tropical elephant grass. J. Anim. Vet. Adv. 3: 116-122.

Yahaya, M. S., M. Goto, W. Yimiti, B. Smerjai, \& Y. Kuwamoto. 2004b. Evaluation of fermentation quality of a tropical and temperate forage crops ensiled with additives of fermented juice of epiphytic lactic acid bacteria (FJLB). Asian-Aust. J. Anim. Sci. 17: 942-946. 